\title{
Use of Baru (Brazilian Almond) Waste from Physical Extraction of Oil to Produce Gluten Free Cakes
}

\author{
Lívia de Lacerda de Oliveira Pineli • Lorena Andrade de Aguiar • Guilherme Theodoro de Oliveira • \\ Raquel Braz Assunção Botelho • Maria do Desterro Ferreira Pereira Ibiapina • \\ Herbert Cavalcanti de Lima $\cdot$ Ana Maria Costa
}

Published online: 11 January 2015

(C) Springer Science+Business Media New York 2015

\begin{abstract}
The extraction of oil from baru almonds produces a waste that carries part of their nutritional qualities and antioxidants. It can be used to produce partially deffated baru flour (PDBF). We aimed to evaluate the applicability of PDBF and the effect of the addition of xanthan gum (XG) to produce gluten free cakes. Cakes were prepared with $100 \%$ wheat flour (WF cake) and with $100 \%$ PDBF and four different levels of XG (0\%-PDBF cake, $0.1 \%$-X1, $0.2 \%$-X2 and $0.3 \%$-X3 cakes), and evaluated for composition, antioxidants, moisture, specific volume, texture and sensory acceptance. PDBF cakes showed lower carbohydrate values, but higher protein, lipids, calories and antioxidant contents. They were rich in fiber, as well as iron, zinc and copper. The replacement of WF by PDBF resulted in an increased hardness and adhesiveness and a decreased cohesiveness, elasticity and moisture. Chewiness of X2 cake was similar to that of WF cake. X2 and $\mathrm{X} 3$ cakes showed specific volume closer to that of WF cake. No difference was found among the treatments for texture and appearance acceptances. Flavor of X2 and X3 cakes were more accepted than WF cake. Acceptance of all cakes were in the liking region of hedonic scale. PBDF associated to XG is a feasible option to substitute WF in gluten free cake, improving its nutritional quality.
\end{abstract}

Electronic supplementary material The online version of this article (doi:10.1007/s11130-014-0460-7) contains supplementary material, which is available to authorized users.

L. d. L. d. O. Pineli $(\bowtie) \cdot$ L. A. de Aguiar • G. T. de Oliveira • R. B. A. Botelho $\cdot$ M. d. D. F. P. Ibiapina

Department of Nutrition, College of Health Sciences, Campus

Universitário Darcy Ribeiro, Universidade de Brasília, Brasília,

DF 70910900, Brazil

e-mail: liviapineli@unb.br

H. C. de Lima • A. M. Costa

Laboratory of Food Science, Embrapa Cerrados, BR 020, Km18,

Planaltina, Federal District 73310970, Brazil
Keywords Baru flour · Cake · Composition · Texture · Acceptance

\section{Introduction}

The study of ecosystems and their species contribute to food security and nutritional improvement. Among the native plants from Brazilian Savannah, Dipteryx alata Vog, popularly known as baru, stands out. It is a drupoide fruit, fibrous, monospermic, ovoid, of brownish hue and smooth texture of the Fabaceae family, with an almond-like seed in its center [1]. Some studies have shown that baru almond presented moisture $(3.49 \mathrm{~g} / 100 \mathrm{~g})$ and protein $(29.92 \mathrm{~g} / 100 \mathrm{~g})$ contents similar to peanuts, but lower concentrations of lipids $(41.95 \mathrm{~g} /$ $100 \mathrm{~g})$ and more total fibers $(2.03 \mathrm{~g} / 100 \mathrm{~g}$ of soluble and $7.18 \mathrm{~g} / 100 \mathrm{~g}$ of insoluble fibers) [2]. Besides, the protein of baru almond can be considered better and more digestible than peanut's [1]. Fernandes et al. [3] also reported high iron (mean $48.1 \mathrm{mg} / \mathrm{kg}$ ) and zinc (mean $46.6 \mathrm{mg} / \mathrm{kg}$ ) contents in these almonds, whereas Lemos et al.[4] showed higher contents of total phenolic compounds than in several other almonds and nuts. Almonds present about $12 \mathrm{~g} / 100 \mathrm{~g}$ of carbohydrates [1]. A content of of $6.06 \mathrm{~g} / 100 \mathrm{~g}$ of starch is reported in solventdeffated flour of baru almonds [5]. Studies have shown that the consumption of baru almonds resulted in a decrease of iron-induced oxidative stress in rats [6] and in an improvement of lipid profile in mildly hypercholesterolemic subjects [7], increasing the interest on this exotic almond and its potential as an ingredient for the food industry.

Physical extraction of baru oil from the almond generates a waste that carries part of its nutritional quality and antioxidants. It can be used to produce partially deffated baru flour (PDBF), dark colored due to the presence of the almonds' peels. The use of PDBF in bakery products need to be studied as prospect of whole use and value addition of the almond, 
besides reduction of food waste. We recently reported the composition of PDBF and its feasibility to produce cookies with partial replacement of wheat flour (WF) [8]. However, the use of PDBF in gluten free products need to be evaluated, specialy in products such as cakes, where the role of starch and proteins of WF are more relevant and complex than in cookies.

The preparation of gluten free products, of great relevance in the treatment of celiac disease [9], requires not only the replacement of wheat, oats, rye or barley flours and grains, but also the use of additives that can positively influence the viscoelasticity of dough and batter, especially gas retention and water absorption. Xanthan gum is one of these additives often used in gluten free products [10]. Therefore, the aim of this study was to evaluate the applicability of PDBF and the effect of the addition of xanthan gum in the preparation of gluten free cakes. We provide new insights into the use of an exotic almond flour in bakery products and the effectiveness of xanthan gum to recover textural properties in a novel gluten free product.

\section{Material and Methods}

\section{Processing of PDBF}

Oil extraction, from which meal was obtained, was performed at the Embrapa Savannah Laboratory of Agro-Energy. Previously, crushed raw almonds (49 kg) were pressed on a continuous screw MPE-40R (Ecirtec, São Paulo, Brazil) with extraction capacity of $40 \mathrm{~L} / \mathrm{h}$. The first $10 \mathrm{~kg}$ were mixed with rice bran $(13 \mathrm{~g} / 100 \mathrm{~g})$ due to its higher percentage of fibers to prevent baru almonds from clogging the press. The remaining $39 \mathrm{~kg}$ were passed with the resulting meal from the first pressing, because it served as source of fiber, allowing the mass to flow through the equipment. PDBF was obtained by grinding the meal in industrial blender for $5 \mathrm{~min}$ and sieving in 32 mesh stainless steel.

\section{Preparation of Cakes}

Cakes were prepared with $100 \%$ of wheat flour (WF) as a control 1 or $100 \%$ of PDBF using the following ingredients flour (100 g), whole milk (100 g), sugar (80 g), egg (50 g), margarine $65 \%$ of lipids (30 g), baking powder ( $3 \mathrm{~g})$, salt $(1 \mathrm{~g})$, and four levels of xanthan gum, ranging from 0 to $0.3 \%$. Mixing was performed manually using a whisk. Salt was added to the wheat flour (WF) or PDBF. Whole eggs and sugar were mixed and then margarine was added. Gradually, flour was added interspersed with milk. When batter was homogeneous, a mix of xanthan gum and baking powder was slowly added. The batters were put in English cake tins $(28.5 \times 11.0 \times 7.0 \mathrm{~cm})$ previously coated with margarine and flour -WF or PDBF- and baked in a preheated electric oven at $180{ }^{\circ} \mathrm{C}$ for $17 \mathrm{~min}$. Cakes were analyzed for nutritional composition, phenolic compounds, besides moisture, specific volume, texture and acceptance whose methods are described in electronic supplementary material. For instrumental analyses, the experimental unit was one cake of approximately $355 \mathrm{~g}$ and we analyzed three experimental units of each treatment, in triplicates. Instrumental data were submitted to ANOVA and significant Fisher test $(p<0.05)$. XLSTAT 2011 program (Addinsoft, Paris, France) was used.

Physical and Chemical Analyzes of Cakes

\section{Composition}

Data from the Brazilian Nutritional Composition Table- TA$\mathrm{CO}$ [11] and the nutritional composition of PDBF, previously obtained in our laboratory [8] were used to take the nutrition facts of all the ingredients and calculate the nutritional composition of the cakes. Proximate analysis was carried out for macronutrients of PDBF whereas minerals were determined by Inductively Coupled Plasma-Atomic Emission Spectrometry. The composition of PDBF was: $3.63 \mathrm{~g} / 100 \mathrm{~g}$ of moisture, $4.70 \mathrm{~g} / 100 \mathrm{~g}$ of ashes, $29.46 \mathrm{~g} / 100 \mathrm{~g}$ of proteins, $11.84 \mathrm{~g} / 100 \mathrm{~g}$ of lipids, $11.57 \mathrm{~g} / 100 \mathrm{~g}$ of carbohydrates, $38.80 \mathrm{~g} / 100 \mathrm{~g}$ of total dietary fibers, $200.91 \mathrm{mg} / 100 \mathrm{~g}$ of calcium, $13.29 \mathrm{mg} /$ $100 \mathrm{~g}$ of iron, $1217.60 \mathrm{mg} / 100 \mathrm{~g}$ of potassium, $7.62 \mathrm{mg} / 100 \mathrm{~g}$ of zinc and $2.04 \mathrm{mg} / 100 \mathrm{~g}$ of cupper.

\section{Total Phenolics, Total Flavonoids and Tannins}

Also for comparison among cakes, phenolic compounds, widely known by their antioxidants properties, were analyzed. Total Phenolics (TP) were quantified using a modified [12] Folin-Ciocalteau colorimetric method [13] and results were expressed as mg of gallic acid equivalent (GAE)/100 g. Total Flavonoids (TF) were analyzed according to the method proposed by Francis [14]. Results were expressed as mg of quercetin equivalent $(\mathrm{QE}) / 100 \mathrm{~g}$. Tannins were quantified using vanillin method [15]. Results were expressed as mg of catechin equivalent $(\mathrm{CE}) / 100 \mathrm{~g}$.

\section{Results and Discussion}

\section{Effects of PDBF on Nutritional Composition of Cakes}

In dry basis, the replacement of WF by PDBF (Table 1) resulted in an increase of $5.5 \%$ in energy value and in a decrease of $39.3 \%$ in carbohydrates. The protein content of the cake increased 2.3-fold, whereas lipids increased $59.9 \%$ and fibers were almost 19.4 times higher. Regarding 
Table 1 Nutritional composition of cakes with wheat flour (WF) and partially defatted baru flour (PDBF)

\begin{tabular}{lcc}
\hline Constituents (g/100 g or mg/100 g, dry basis) & WF cake & PDBF cake \\
\hline Calories (kcal) & 415 & 438 \\
Carbohydrates (g) & 67.3 & 46.8 \\
Proteins (g) & 8.5 & 19.2 \\
Lipids (g) & 12.4 & 19.2 \\
Total fibers (g) & 1.0 & 18.5 \\
Ca (mg) & 70.31 & 170.31 \\
Fe (mg) & 0.85 & 6.88 \\
Na (mg) & 378.51 & 452.05 \\
K (mg) & 238.19 & 791.54 \\
Zn (mg) & 0.73 & 4.12 \\
Cu (mg) & 0.02 & 0.30 \\
Total phenolics (mg GAE) & $51.8^{\mathrm{b}} \pm 5.0$ & $185.6^{\mathrm{a}} \pm 7.0$ \\
Total flavonoids (mg QE) & $2.4^{\mathrm{b}} \pm 0.02$ & $43.1^{\mathrm{a}} \pm 9.7$ \\
Tannins (mg CE) & $8.9^{\mathrm{b}} \pm 2.3$ & $101.3^{\mathrm{a}} \pm 2.8$ \\
\hline
\end{tabular}

${ }^{1}$ Nutritional composition of the regular ingredients were taken from NEPA/TACO [11] and composition data of PDBF were taken from Pineli et al. [8]. For total phenolics, total flavonoids, tannins and moisture, means followed by same letters in the rows do not differ according to $t$ test $(\mathrm{p}<0.05)$. Results from three cakes analysed in triplicate

micronutrient, there was an increase in dry basis, of 7.8 times in iron, 2.4 times in calcium, 3.2 times in potassium, 5.5 times in zinc and 15 times in copper, whereas sodium concentration increased only $15.7 \%$.

The nutritional composition of PDBF cake is better evaluated when it is also analysed in fresh basis (data not shown), as it will be actually consumed. According to the Brazilian legislation [16], the PDBF cake can be labeled as high protein content since it presents more than $12 \mathrm{~g}$ in $100 \mathrm{~g}$. Cakes produced with PDBF present high iron content representing $73.7 \%$ of men Estimated Average Requirement (EAR) and $55.3 \%$ of women EAR [17]. Zinc content is lower than iron, but it can be labeled as high according to Brazilian legislation, being $28.1 \%$ of men EAR and $38.8 \%$ of women EAR. For copper, $100 \mathrm{~g}$ of cake represents $91.4 \%$ of the recommended intake. However, cakes cannot be labeled as high in calcium content.

PDBF cakes are considered rich in fiber according to the Brazilian legislation, as it presented more than $6 \mathrm{~g}$ of fiber in $100 \mathrm{~g}$ of the product [16]. PDBF showed higher fiber content because of the almonds' peels and the addition of rice bran during pressing.

The lipids content in PDBF was high and consistent with physical oil extraction of baru almonds, retaining part of the lipids in the waste. Lipid fraction of baru almonds presents high content of $\alpha$ - tocopherol $(5 \mathrm{mg} / 100 \mathrm{~g}$ ) and it is similar in composition to peanut oil fatty acids, especially for oleic $(50.4 \%)$ and linoleic $(28 \%)$ acids [2]. Therefore, despite the increase in lipid content in PDBF cake, it is believed that the substitution of WF by PDBF contributes to the nutritional composition of cakes. It is also important to consider that the lower amount of carbohydrates as well as the increased fiber content, lipids and proteins, as we observed in PDBF cakes, may contribute to the reduction of the glycemic index (GI) of the products [18].

For antioxidants variables, the replacement of WF by PDBF in dry basis resulted in a 3.6 times increase of total phenolics and 18-fold higher amounts of flavonoids in cakes. Indeed, baru almonds have levels of total phenolic around $550 \mathrm{mg}$ GAE / $100 \mathrm{~g}$, greater than several other almonds (pine nuts, macadamia nuts, Brazil nut, cashew nut, hazelnut and peanut). More than $50 \%$ of antioxidants and more than $90 \%$ of in vitro antioxidant activity are located in almond's skin [4]. The in vivo antioxidant activity associated to phenolic compounds was also observed in a study with rats subjected to oxidative stress induced by iron that consumed baru almonds [6].

Tannins were increased approximately 12 -fold and the concentrations found in PDBF cakes were similar to tannins in wines [19]. Besides antioxidant, anticarcinogenic and antimutagenic properties [20], tannins may also influence GI by the inhibition of the digestive enzymes $\alpha$-amylase and glucoamylase, thereby reducing starch hydrolysis [21].

\section{Effect of PDBF on Physical Properties of Cake}

The attributes of hardness, cohesiveness and elasticity showed no difference between the treatments with different levels of xanthan gum compared to PDBF control cake (Table 2). We observed an average increase in hardness of 3.5 times, and a decrease in cohesiveness and elasticity of 38 and $30 \%$, respectively, when PDBF replaced WF.

The mechanical changes attributed to the replacement of WF by PDBF in cakes are related to the increase of fibers and liquid oil, to gluten absence, despite the high content of proteins in PDBF, and to carbohydrates reduction (mainly starch). Starch and gluten, even with a limited development of gluten network in cake batter, with egg protein, play a decisive role in cake quality [22]. The replacement of WF by other flours may result in higher protein levels, losing however, the functionality of the gluten network. Similar results were found by De la Hera et al. [23], who studied the replacement of WF with lentil flour in layer and sponge cakes, and also reported reduced volume, cohesiveness and elasticity besides increased hardness. Air incorporation, lubrication, heat transfer, tenderness, moisture, mouthfeel, flavor, structure, and shelf life of cakes are affected by lipids [24], but it depends on solid fat index (SFI). Low SFI lipids, such as liquid oil found in PDBF, do not have the ability to hold the air until mixing is complete [25]. Besides, the addition of fibers in gluten free cakes, despite the relevance from the standpoint of nutritional deficiencies of the celiac diet [26], reduces the incorporation of air into the batter, which 
Table 2 Physical analysis of cakes with Wheat Flour, and Partially Deffated Baru Flour with different levels of Xanthan Gum

\begin{tabular}{|c|c|c|c|c|c|}
\hline Treatment & WF & PDBF & $\mathrm{X} 1$ & $X 2$ & $\mathrm{X} 3$ \\
\hline Hardness (gF) & $690.1^{\mathrm{b}} \pm 66.4$ & $2227.5^{\mathrm{a}} \pm 288.0$ & $2594.3^{\mathrm{a}} \pm 478.7$ & $2169.2^{\mathrm{a}} \pm 206.2$ & $2638.8^{\mathrm{a}} \pm 130.6$ \\
\hline Cohesiveness (-) & $0.6^{\mathrm{a}} \pm 0.02$ & $0.4^{\mathrm{b}} \pm 0.02$ & $0.4^{\mathrm{b}} \pm 0.03$ & $0.4^{\mathrm{b}} \pm 0.05$ & $0.4^{\mathrm{b}} \pm 0.03$ \\
\hline Adhesiveness (mJ) & $0.140^{\mathrm{c}} \pm 0.01$ & $0.473^{\mathrm{b}} \pm 0.01$ & $0.480^{\mathrm{b}} \pm 0.04$ & $0.495^{\mathrm{b}} \pm 0.01$ & $0.545^{\mathrm{a}} \pm 0.03$ \\
\hline Elasticity (mm) & $11.2^{\mathrm{a}} \pm 0.9$ & $8.5^{\mathrm{b}} \pm 1.7$ & $8.3^{\mathrm{b}} \pm 1.7$ & $7.1^{\mathrm{b}} \pm 0.8$ & $7.6^{\mathrm{b}} \pm 1.6$ \\
\hline Chewiness (mJ) & $43.9^{c} \pm 6.6$ & $70.7^{\mathrm{ab}} \pm 11.1$ & $80.3^{\mathrm{a}} \pm 13.0$ & $55.5^{\mathrm{bc}} \pm 4.3$ & $68.5^{\mathrm{ab}} \pm 9.3$ \\
\hline Moisture (g.100 $\left.\mathrm{g}^{-1}\right)$ & $38.0^{\mathrm{a}} \pm 0.7$ & $36.0^{\mathrm{b}} \pm 0.1$ & $36.9^{\mathrm{b}} \pm 0.4$ & $36.8^{\mathrm{b}} \pm 0.2$ & $36.3^{\mathrm{b}} \pm 1.0$ \\
\hline Specific volume $\left(\mathrm{cm}^{3} / \mathrm{g}\right)$ & $2.7^{\mathrm{a}} \pm 0.3$ & $1.2^{\mathrm{c}} \pm 0.3$ & $1.3^{\mathrm{c}} \pm 0.1$ & $2.0^{\mathrm{b}} \pm 0.5$ & $1.6^{\mathrm{bc}} \pm 0.1$ \\
\hline
\end{tabular}

$W F$ wheat flour cake, $P D B F$ cake with partially deffated baru flour (PDBF) and no xanthan gum; X1- cake with PDBF with $0.1 \%$ of xanthan gum; X2 - cake with PDBF with $0.2 \%$ of xanthan gum; X3 - cake with PDBF with $0.3 \%$ of xanthan gum. Means followed by the same lowercase letters do not differ by Fisher's test $(p<0.05)$. Results of three cakes analysed in triplicate

adversely affects cake texture and volume [27]. In a study with increasing levels of replacement of wheat flour by apple pomace flour, rich in pectin, Massodi et al. [28] also observed the decrease of cake volume.

Only PDBF cake with $0.2 \%$ of xanthan gum was comparable with WF control 1 for chewiness. Instrumental chewiness is the result of multiplying hardness, cohesiveness and elasticity. Therefore, similar value of $X 2$ cake to the WF control cake for chewiness suggests that treatment with PDBF and $0.2 \%$ of xanthan gum, for a combination of mechanical variables, is what most resembled the conventional cake.

Adhesiveness increased 3.6 times after the replacement of WF by PDBF. The addition of $0.3 \%$ of GX resulted in increased adhesiveness, $13 \%$ higher compared to the average of the other treatments with PDBF. Indeed, studies report the adhesive properties of gums [29] and lipids [30].

We also observed that the moisture of WF cake was $5.5 \%$ superior to those of PDBF cakes (Table 1). Differences in moisture of wheat flour, around $14 \mathrm{~g} / 100 \mathrm{~g}$ [11], and PDBF, $3.6 \mathrm{~g} /$ $100 \mathrm{~g}$ [8] may be one of the reasons. Furthermore, it is possible that the structure of WF cake presents higher gas retention capacity and water vapor, which contributes to the expansion of the mass and its moisture after cooling. When the cake is removed from the oven, it cools and the gases contract or condense [31].

With respect to specific volume, WF cake of the present study was close $\left(2.7 \mathrm{~cm}^{3} / \mathrm{g}\right)$ to the results found in the literature for the cupcakes made with partially deffated peanut meal [32]. As expected, PDBF resulted in lower specific volume because of the absence of gluten functionality [33]. However, the treatment with $0.2 \%$ of xanthan gum was the closest one to the value found for WF cake, which indicates the role of XG to recover specific volume in gluten free PDBF cakes.

\section{Effects of PDBF on Acceptance of Cakes}

Neither the replacement of WF by PDBF nor the addition of xanthan gum changed cakes' acceptance, regarding overall liking, appearance and texture (Table 3). This result is better than that found by Chavan et al. [32] who observed a reduction in the acceptance of cupcakes made with partially defatted peanut flour. For flavor, there was slightly higher acceptance of PDBF cakes with 0.2 or $0.3 \%$ of xanthan gum, compared with WF cake. The role of xanthan gum in flavor is still unclear, however, xanthan gum pseudoplasticity is known to improve flavor release in food [34]. For all treatments, sensory acceptance stood in the region of acceptance of hedonic scale. Then, despite the significant changes observed in composition, texture and volume, PDBF cakes are acceptable and thus feasible. It is noteworthy that all the criteria to minimize physicological errors in the sensory tests were carried out, such as randomized and monadic presentation, control of samples temperature and homogeneity. However, WF cakes and PDBF cakes are far different from each other, which makes probable the occurrence of psychological effects, probably resulting in the reduction of acceptance scores of either WF cakes by group effect or PDBF cakes by contrast effects [35]. Halo effect is also common in tests in which consumers provide responses to product acceptance followed by responses to a set of attributes [35]. Therefore, in this study, the preference by PDBF cakes, probably drove by appearance and/or flavor, once it looks like a chocolate cake and tastes like nut cakes, sometimes preferred over white common cakes,

Table 3 Acceptance of cakes with Wheat Flour, and Partially Deffated Baru Flour with different levels of xanthan gum

\begin{tabular}{lrllll}
\hline & \multicolumn{1}{l}{ WF } & PDBF & \multicolumn{1}{l}{ X1 } & \multicolumn{1}{l}{ X2 } & \multicolumn{1}{l}{ X3 } \\
\hline Appearance & $6.8^{\mathrm{a}} \pm 1.5$ & $6.9^{\mathrm{a}} \pm 1.8$ & $6.6^{\mathrm{a}} \pm 1.7$ & $6.6^{\mathrm{a}} \pm 1.6$ & $6.9^{\mathrm{a}} \pm 1.5$ \\
Flavor & $6.3^{\mathrm{ab}} \pm 1.7$ & $5.8^{\mathrm{b}} \pm 2.2$ & $6.2^{\mathrm{ab}} \pm 1.9$ & $6.5^{\mathrm{a}} \pm 1.7$ & $6.3^{\mathrm{a}} \pm 1.6$ \\
Texture & $6.4^{\mathrm{a}} \pm 1.7$ & $6.7^{\mathrm{a}} \pm 1.9$ & $6.8^{\mathrm{a}} \pm 1.6$ & $6.6^{\mathrm{a}} \pm 1.6$ & $6.7^{\mathrm{a}} \pm 1.6$ \\
Overall liking & $6.4^{\mathrm{a}} \pm 1.6$ & $6.4^{\mathrm{a}} \pm 2.0$ & $6.7^{\mathrm{a}} \pm 1.5$ & $6.6^{\mathrm{a}} \pm 1.4$ & $6.6^{\mathrm{a}} \pm 1.4$
\end{tabular}

WF - wheat flour cake; PDBF - cake with Partially deffated baru flour (PDBF) and no xanthan gum; X1- cake with PDBF with $0.1 \%$ of xanthan gum; X2 - cake with PDBF with $0.2 \%$ of xanthan gum; X3 - cake with PDBF with $0.3 \%$ of xanthan gum. Means followed by the same lowercase letters do not differ by Fisher's test $(p<0.05)$ 
must have raised the overall liking scores and, by halo effect, influenced positively the texture scores of PDBF cakes. The stronger effects of some attributes that are the drivers of liking, as studied by Morais et al. [36], make the other characteristics, even negative ones, less important to the general acceptance. The same might have happened for texture and, as a result, for the overall liking of PDBF cakes in this study.

\section{Conclusion}

The substitution of WF by PDBF resulted in cakes with higher concentrations of proteins, lipids, soluble and insoluble fiber and phenolic antioxidants. There was an increase in calcium, iron, zinc, copper and potassium, and no significant changes in the levels of sodium. There was a reduction in the concentration of carbohydrates, which, in association to tannins, may be interesting to lower the glycemic index of cakes. There was an increase of hardness and adhesiveness, as well a reduction of cohesiveness, elasticity, moisture and specific volume of PDBF cakes. The addition of $0.3 \%$ xanthan gum caused a larger increase in adhesiveness. Cakes with $0.2 \%$ xanthan gum showed properties of chewiness and specific volume closer to the WF cake. Despite the physical changes, PDBF cakes with different levels of xanthan gum were well accepted, indicating the feasibility of this flour in the preparation of healthier cakes, contributing to the diversification of diets by the valorization of a product from the Brazilian savannah. It will also help to vary coeliac disease patients diets with a low cost product that is considered a waste from the baru oil extraction. Further studies for the improvement of the texture of PDBF cakes should include the addition of starchy ingredients and other gums.

Acknowledgement Acknowledgement to CNPq for financial support.

Conflict of Interest Lívia de L. de O. Pineli declares that she has no conflict ofinterest.

Lorena A. de Aguiar declares that she has no conflict of interest.

Guilherme T. de Oliveira declares that he has no conflict of interest.

Raquel B. A. Botelho declares that she has no conflict of interest.

Maria do Desterro F.P. Ibiapina declares that she has no conflict of interest.

Herbert C. de Lima declares that he has no conflict of interest.

Ana Maria Costa declares that she has no conflict of interest.

\section{References}

1. Sousa AGO, Fernandes DC, Alves AM, Freitas JB, Naves MMV (2011) Nutritional quality and protein value of exotic almonds and nut from the Brazilian Savanna compared to peanut. Food Res Int 44: 2319-2325
2. Takemoto E, Okada IA, Garbelotti ML, Tavares M, Aued-Pimentel S (2001) Chemical composition of baru (Dypterix alata Vog.) seed and oil. Rev Inst Adolfo Lutz 60:113-117, ID: 339396

3. Fernandes DC, Freitas JB, Czeder LP, Naves MMV (2010) Nutritional composition and protein value of the baru (Dipteryx alata Vog.) almond from the Brazilian Savanna. J Sci Food Agric 90:1650 1655

4. Lemos MRB, Siqueira EM, Arruda SF, Zambiazi RC (2012) The effect of roasting on the phenolic compounds and antioxidant potential of baru nuts [Dipteryx alata Vog.]. Food Res Int 48:592-597

5. Guimarães RCA, Favaro SP, Viana ACA, Braga Neto JA, Neves VA, Honer MR (2012) Study of the proteins in the defatted flour and protein concentrate of baru nuts (Dipteryx alata Vog). Food Sci Technol 32:464-470. doi:10.1590/S0101-20612012005000065

6. Siqueira E, Marin A, Cunha M, Fustinoni A, Sant'ana L, Arruda SF (2012) Consumption of baru seeds [Dipteryx alata Vog.], a Brazilian savanna nut, prevents iron-induced oxidative stress in rats. Food Res Int 45:427-433

7. Bento A, Cominetti C, Simões Filho A, Naves M (2014) Baru almond improves lipid profile in mildly hypercholesterolemic subjects: a randomized, controlled, crossover study. Nutr Metab Cardiovasc Dis. doi:10.1016/j.numecd.2014.07.002

8. Pineli LLO, Carvalho M, Aguiar L, Oliveira G, Celestino S, Botelho R, Chiarello M (2015) Use of baru (Brazilian almond) waste from physical extraction of oil to produce flour and cookies. LWT - Food Sci Technol 60:50-55. doi:10.1016/j.lwt.2014.09.035

9. Feighery C (2009) Fortnightly review: coeliac disease. BMJ 319: 236-239, PMC1116331

10. Preichardt LD, Vendruscolo CT, Gularte MA, Moreira AS (2011) The role of xanthan gum in the quality of gluten free cakes: improved bakery products for coeliac patients. Int J Food Sci Technol 46:25912597

11. NEPA/TACO (2011). Brazilian nutritional composition Table (4th ed.) NEPA UNICAMP, Campinas.

12. Pineli LLO, Moretti CL, Santos MS, Campos AB, Brasileiro AV, Cordova AC, Chiarello MD (2011) Antioxidants and other chemical and physical characteristics of two strawberry cultivars at different ripeness stages. J Food Comp Anal 24:11-16

13. Singleton V, Orthofer R, Lamuela-Raventós R (1999) Analysis of total phenols and other oxidation substrates and antioxidants by means of Folin-Ciocalteu reagent. Methods Enzymol 299:152-315

14. Francis FJ (1982) Analysis of anthocyanins. In: Markakis P (ed) Anthocyanins as food colors. Academic, New York

15. Broadhurst RB, Jones WT (1978) Analysis of condensed tannins using acidified vanillin. J Sci Food Agric 29:788-794

16. Brazilian National Health Surveillance Agency (2012) Board Resolution - RDC N ${ }^{\circ}$ 54/ 2012. Providing on the Technical Regulation on Nutritional Supplementary Information http://portal.anvisa.gov.br/wps/ wcm/connect/630a98804d7065b981f1e1c116238c3b/Resolucao+ RDC + n. +54 2012.pdf?MOD=AJPERES. Accessed: 12 Apr 2014

17. IOM (2006) Dietary reference intakes: the essential guide to nutrient requirements, 1st edn. The National Academies Press, Washington

18. Jenkins DJ, Wolever TM, Taylor RH, Barker H, Fielden H, Baldwin JM, Bowling AC, Newman HC, Jenkins AL, Goff DV (1981) Glycemic index of foods: a physiological basis for carbohydrate exchange. Am J Clin Nutr 34:362-366

19. Mattivi F, Vrhovsek U, Masuero D, Trainotti D (2009) Differences in the amount and structure of extractable skin and seed tannins amongst red grape varieties. Australian J Grape Wine Res 15:27-35

20. Amarowicz R (2007) Tannins: the new natural antioxidants? Eur J Lipid Sci Technol 109:549-551

21. Barrett A, Ndou T, Hughey C, Straut C, Howell A, Dai Z, Keletunc G (2013) Inhibition of $\alpha$ amylase and glucoamylase by tannins extracted from cocoa, pomegranates, cranberries, and grapes. J Agric Food Chem 61:1477-1486 
22. Wilderjans E, Luyts A, Brijs K, Delcour JA (2013) Ingredient functionality in batter type cake making. Trends Food Sci Technol 30:6-15

23. De la Hera E, Ruiz-París E, Oliete B, Gómez M (2012) Studies of the quality of cakes made with wheat-lentil composite flours. LWT-Food Sci Technol 49:48-54

24. Zhong H, Allen K, Martini S (2014) Effect of lipid physical characteristics on the quality of baked products. Food Res Int 55:239-246

25. O'Brien RD (2004) Fats and oils. Formulating and processing for applications, 2nd edn. CRC Press, Washington

26. Gularte MA, de la Hera E, Gómez M, Rosell CM (2012) Effect of different fibers on batter and gluten-free layer cake properties. LWT Food Sci Technol 48:209-214. doi:10.1016/j.lwt.2012.03.015

27. Gomez M, Moraleja A, Oliete B, Ruiz E, Caballero PA (2010) Effect of fibre size on the quality of fibre-enriched layer cakes. LWT Food Sci Technol 43:33-38. doi:10.1016/j.lwt.2009.06.026

28. Massoodi FA, Sharma B, Chauan GS (2002) Use of apple pomace as a source of dietary fiber in cakes. Plant Foods Hum Nutr 57:121-128

29. Armstrong ME, Barringer SA (2013) Improving adhesion of seasonings to crackers with hydrocolloid solutions. J Food Sci 78:E1704-12
30. Michalski MC, Desobrya S, Ponsb M-N, Hardy J (1998) Adhesion of edible oils to food contact surfaces. J Am Oil Chem Soc 75:447-454. doi:10.1007/s11746-998-0247-9

31. Wilderjans E, Pareyt B, Goesaert H, Brijs K, Delcour JA (2008) The role of gluten in a pound cake system: a model approach based on gluten-starch blends. Food Chem 110:909-915

32. Chavan JK, Shinde VS, Kadam SS (1991) Utilization of expeller pressed partially defatted peanut cake meal in the preparation of bakery products. Plant Foods Hum Nutr 41:253-259

33. Sharma HR, Chauhan GS (2000) Physicochemical and rheological quality characteristics of fenugreek (Trigonella foenumgraecum L.) supplemented wheat flour. J Food Sci Technol 37:87-90, Record number: 20026788184

34. Sworn G (2009) Xanthan Gum. In. Phillips, GO; Willians, PA (ed) Handbook of hydrocolloids. Boca Raton: CRC Press.

35. Stone H, Sidel J (2004) Sensory evaluation practices, 3rd edn. Academic, San Diego

36. Morais EC, Cruz AG, Faria JAF, Bolini HMA (2014) Prebiotic gluten-free bread: sensory profiling and drivers of liking. LWT Food Sci Technol 55:248-254. doi:10.1016/j.lwt.2013.07.014 